\title{
Test of Spanish sentences to measure speech intelligibility in noise conditions
}

\author{
Teresa Cervera • Julio González-Alvarez
}

Published online: 17 March 2011

(C) Psychonomic Society, Inc. 2011

\begin{abstract}
This article describes the development of a test for measuring the intelligibility of speech in noise for the Spanish language, similar to the test developed by Kalikow, Stevens, and Elliot (Journal of the Acoustical Society of America, 5, 1337-1360, 1977) for the English language. The test consists of six forms, each comprising 25 highpredictability (HP) sentences and 25 low-predictability (LP) sentences. The sentences were used in a perceptual task to assess their intelligibility in babble noise across three different signal-to-noise ratio (SNR) conditions in a sample of 474 normal-hearing listeners. The results showed that the listeners obtained higher scores of intelligibility for HP sentences than for LP sentences, and the scores were lower for the higher SNRs, as was expected. The final six forms were equivalent in intelligibility and phonetic content.
\end{abstract}

Keywords Speech perception - Auditory perception . Intelligibility $\cdot$ Masking noise

The assessment of speech intelligibility plays an important role in fields such as audiology, psychoacoustics, and telecommunications, among others. The use of sentence materials to test speech intelligibility has many advantages

T. Cervera $(\triangle)$

Departamento de Psicologia Básica, Facultad de Psicologia, Universidad de Valencia,

Blasco Ibanez 21,

46010 Valencia, Spain

e-mail: Teresa.Cervera@uv.es

J. González-Alvarez

University Jaume I,

Castellón, Spain over using other types of speech stimuli, such as words or syllables, because sentences are more representative of real everyday communicative situations than are words or syllables. On the other hand, these types of stimuli have some disadvantages. For example, if the experimenter uses different experimental conditions, such as different signalto-noise ratios (SNRs) or other listening conditions, the same speech materials cannot be repeated with the same listener.

To address this issue, Kalikow, Stevens, and Elliot (1977) developed a test of speech perception in noise (SPIN) consisting of eight lists of sentences equivalent in intelligibility and tested in different conditions of background babble noise. Thus, an experimenter can select some of these lists and use them in different experimental listening conditions simulating those encountered in everyday speech communication.

The SPIN sentences have another valuable characteristic. Each 50-sentence list contains 25 high-predictability (HP) sentences and 25 low-predictability (LP) sentences. The HP sentences are constructed in such a way that the final word can somehow be predicted by the preceding context, and the LP sentences are constructed in such a way that the final word cannot be predicted by the context. Each HP sentence has its corresponding LP sentence, so that the same final word appears in both the HP sentence and its corresponding LP sentence. The listeners must respond by providing the final word or key word. Comparing the performance of individuals on the recognition of these two types of sentences makes it possible to assess the separate effects of auditory acuity and linguistic knowledge, expressed as the capability of using the preceding context to recognize the final word. Thus, the contribution of either sensory or cognitive processing to the total score obtained by the listener can be estimated by comparing performances on the 
HP and LP sentences. The assumption is that the HP sentences produce higher scores than do the LP sentences, especially in adverse listening conditions. In these situations, when the acoustical cues and bottom-up processing are not enough to accomplish speech perception, top-down processing (linguistic knowledge or the use of context) can facilitate this identification.

The evaluation of speech intelligibility is especially important in adverse listening conditions that simulate everyday listening situations, such as background noise at different signal-to noise levels (Dubno, Ahlstrom, \& Horwitz, 2000; Gordon-Salant \& Fitzgibbons, 1999, 2001, 2004; Gordon-Salant, Fitzgibbons, \& Friedman, 2007; Humes, Burk, Coughlin, Busey, \& Strauser, 2007; Kalikow et al., 1977), fast speech (Gordon-Salant \& Fitzgibbons, 1999, 2001, 2004; Gordon-Salant et al., 2007; Humes et al., 2007), same versus different speakers' voices (Goy, Pichora-Fuller, van Lieshout, Singh, \& Schneider, 2007), or some speech distortions such as jitter (Pichora-Fuller, Schneider, MacDonald, Pass, \& Brown, 2007) or noise-vocoded speech (Sheldom, Pichora-Fuller, \& Schneider, 2008).

Another area in which the measurement of speech intelligibility is especially relevant is clinical audiology. The SPIN test has demonstrated its clinical utility in measuring the effects of linguistic cues on speech discrimination in studies by Bilger, Nuetzel, Rabinowitz, and Rzeczkowsky (1984) and Hutcherson, Dirks, and Morgan (1979) for listeners with sensorineural hearing loss or in the study by Del Dot, Hickson, and O'Connell (1992) for listeners using hearing aids.

There are many other situations in which testing the effects of linguistic knowledge is a relevant issue. For instance, the study by Elliot (1979) evaluated from what age children are able to use contextual or linguistic cues to achieve speech perception in noise, while the study by Mayo, Florentine, and Buus (1997) determined how age of acquisition influences second-language speech perception. In the latter study, differences in the recognition of HP and LP sentences, especially in noise conditions, would indicate the degree to which the nonnative listeners had mastered the ability to profit from the semantic and syntactic information provided by the context.

Another research area of interest is the recognition of speech in noise in elderly listeners. The differences these listeners show for the HP versus LP sentences have been extensively studied (Dubno et al., 2000; Gordon-Salant \& Fitzgibbons, 1997; Perry \& Wingfield, 1994; Pichora-Fuller, 2008; Pichora-Fuller, Schneider, \& Daneman, 1995; Sommers \& Danielson, 1999; Wingfield, Tun, \& McCoy, 2005). In these listeners, decreases in sensory information due to loss of hearing acuity, especially in adverse listening conditions, can be com- pensated by information provided by the context (Pichora Fuller, 2008).

Thus, the SPIN test has been applied to a variety of experimental conditions and types of listeners in the English language, and it has proved to be a useful tool in psycholinguistics, psychoacoustics, and audiology. The objective of the present study was to develop a test to measure the intelligibility of speech in noise for the Spanish language similar to the test developed by Kalikow et al. (1977) for the English language in an experiment conducted to measure the intelligibility of a pool of sentences with different signal-to-noise ratios (SNRs). These sentences were used in a previous study (Cervera \& GonzalezAlvarez, 2010). In that study, six lists of HP sentences were first generated. These lists had equivalent predictability for the final word. They were also equivalent in length, phonetic content of the sentence, and frequency of the final word. In addition, each HP sentence had its corresponding LP sentence generated by using the same final word but with an LP preceding context, producing six corresponding LP lists.

In the present study, our aim was to assess the intelligibility of these sentences in normal-hearing listeners in three different SNR conditions $(0 \mathrm{~dB},+5 \mathrm{~dB}$, and $+10 \mathrm{~dB})$ using babble noise. We hypothesized that the performance of the listeners on the HP sentences would be higher than the performance on the LP sentences. At the same time, among the three SNR conditions, the $+10-\mathrm{dB}$ SNR condition would produce higher scores than the $+5-\mathrm{dB}$ SNR condition, and the latter would produce higher scores than the $0-\mathrm{dB}$ SNR condition.

The ultimate objective was to create a set of final lists (hereafter referred to as forms) of equal intelligibility to be used as a test of speech intelligibility in noise for the Spanish language. These forms consist of 50 sentences each ( $25 \mathrm{HP}$ and $25 \mathrm{LP}$ ). The forms must also have equivalent phonetic content, because this characteristic is very important in audiology.

\section{Method}

Participants

The participants in the experiment were 474 undergraduate students, 394 from the University of Valencia and 80 from the University of Jaume I. Of these students, 291 were female and 183 were male. Their ages ranged from 21 to 30 years, with a mean age of 23.1 years $(S D=2.6)$. They received partial credit for a course requirement. None of the participants reported having any hearing or language problems, and they were native speakers of Castilian Spanish. 
Stimuli

The stimuli consisted of $150 \mathrm{HP}$ sentences and $150 \mathrm{LP}$ sentences. These sentences were generated in a previous study (Cervera \& Gonzalez-Alvarez, 2010). The HP sentences consisted of sentences whose final word was in some way predictable from the preceding context, with values of between $10 \%$ and $90 \%$ predictability (e.g., "Ata el regalo con una cinta"; "Tie the present with a ribbon"). The 150 sentences were grouped in six lists so that the predictability of all of the six lists was equivalent. These lists were also equivalent in length (all of them had from seven to ten syllables), phonetic content (with regard to both the whole sentence and only the last word or key word), syllabic structure, word stress, and frequency of the final word.

In addition, each HP sentence had its corresponding LP sentence, generated using the same final word, but with an LP preceding context. An example would be "Ahora voy a decir cinta" ("Now I am going to say ribbon"). Thus, six lists of $25 \mathrm{HP}$ sentences and six lists of $25 \mathrm{LP}$ sentences were created.

These lists were recorded by a native Castilian Spanish female speaker who was accustomed to recording for experimental or clinical purposes. The speaker was required to repeat each sentence 3 times. In addition, the duration of the utterance had to be from 1,800 to $2,000 \mathrm{~ms}$. The clearest production of each sentence recording was selected. The recording took place in a soundproof room, using a Sennheiser HMD 224 microphone set at $15 \mathrm{~cm}$ from the lips and directly digitalized in the computer using an Edirol UA-5 sound card, with a sampling frequency of $11.025 \mathrm{kHz}$, and then the signal was low-pass filtered at $5.5 \mathrm{kHz}$ to prevent aliasing.

The speech materials were edited with Adobe Audition sound editor software. First, each sentence was excised from the recorded list of sentences, creating WAV files of 1,800 $2,000 \mathrm{~ms}$ of duration. Visual inspection of the waveform and the spectrogram was used to determine optimal points at which to excise the sentence. Then the intensity of each stimulus was also adjusted so that it would have an equal rootmean square (RMS) across the entire sentence. The final words of the sentences were also equal in intensity.

To create the masking condition, we used babble noise. The babble noise was generated by mixing 12 voices (six males and six females) reading a text. The recording conditions and digitalization of the signal were the same as in the case of the sentence stimuli. The babble noise was mixed with each sentence, creating each of the three SNR conditions, $0-\mathrm{dB},+5-\mathrm{dB}$, and $+10-\mathrm{dB}$ SNR, by manipulating the overall RMS of both the signal and the babble noise. These manipulations were performed using Adobe Audition Pro software.
Procedure

The six lists of HP sentences and the six lists of LP sentences were presented in three different conditions of background noise $(0-\mathrm{dB},+5-\mathrm{dB},+10-\mathrm{dB}$ SNR $)$ to a group of 474 listeners. Each individual was presented randomly with one of the following combinations of the HP and LP lists: list 1 (HP) with list 2 (LP), list 2 (HP) with list 3 (LP), list 3 (HP) with list 4 (LP), list 4 (HP) with list 5 (LP), list 5 (HP) with list 6 (LP), and list 6 (HP) with list 1 (LP). By means of these combinations, each participant was presented with both HP and LP sentences, but with no repetition of the final word of the sentence. At the same time, each individual was presented with only one of the three SNR conditions randomly. Thus, 79 individuals completed each of the six list combinations described above. Of each of these 79 participants, 26 of them were presented with the 0-SNR condition, 26 of them were presented with the +5 -SNR condition, and 27 of them were presented with the $+10-\mathrm{SNR}$ condition.

The listeners participated in the experiment in a soundattenuated laboratory with six cabins. Each cabin contained a Pentium PC with Sennheiser headphones. Before the experiment began, participants were instructed to listen to the sentence and enter the last word of the sentence, using the computer keyboard. The administration of the stimulus and the registration of the responses made by the listener were performed by a Java program developed specifically for this experiment.

\section{Results}

\section{Percent correct scores}

Figure 1 shows the mean scores (expressed in percentages) obtained by the listeners on the perceptual test for both the HP and the LP sentences in the three conditions of background noise, $0 \mathrm{~dB},+5 \mathrm{~dB}$, and $+10 \mathrm{~dB}$ SNR. For each condition of SNR and for HP and LP sentences, the percentiles of the data obtained by the listeners were calculated as well (see Table 1).

As can be observed in Fig. 1, the HP sentences presented higher perceptual scores than did the LP sentences, as was hypothesized. At the same time, the perceptual scores were higher for the highest SNR condition, $+10 \mathrm{~dB}$, followed by the $+5-\mathrm{dB}$ condition, and the lower scores correspond to the $0-\mathrm{dB}$ condition, as was hypothesized.

With the aim of testing whether the differences between the LP and the HP sentences and the differences in the three conditions of SNR were significant, we submitted the data to a two-way ANOVA with percentage of correct scores obtained on the intelligibility test as a dependent measure 


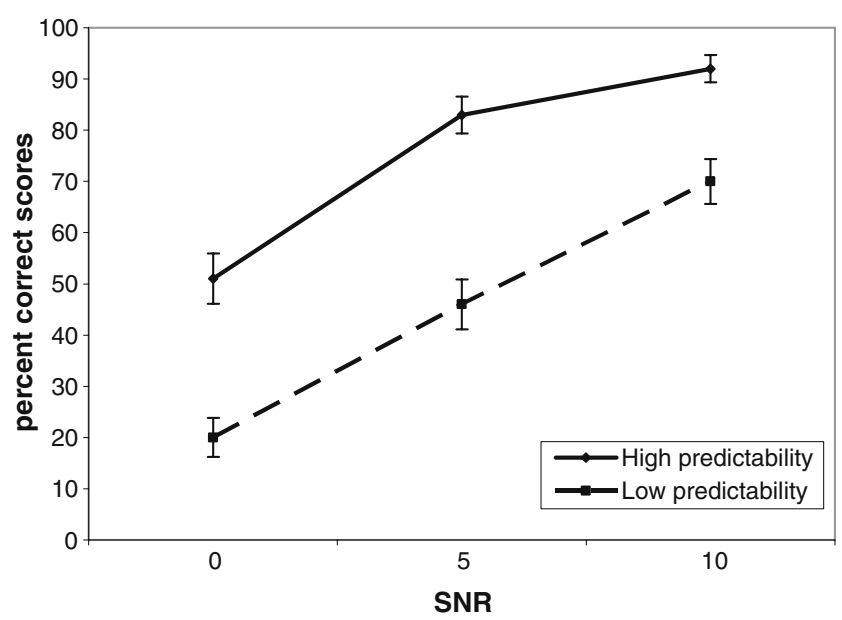

Fig. 1 Means of the percentage of correct identification scores in three signal-to-noise ratio (SNR) conditions for high-predictability sentences and low-predictability sentences. Error bars indicate standard errors

and type of sentence (HP or LP) and the three SNR conditions $(0 \mathrm{db},+5 \mathrm{~dB}$, and $+10 \mathrm{~dB})$ as factors or independent variables.

We found significant main effects of type of sentence, $F(1)=3,005.19, p<.01, \eta^{2}=.11$, and SNR condition, $F(2)=2,234.43, p<.01, \eta^{2}=.16$. The interaction was also significant, $F(1,2)=77.66, p<.01$, $\eta^{2}=.007$. A posteriori comparisons of the levels of the SNR factor, by means of the Tukey test, showed significant differences between 0 and $+5 \mathrm{~dB}(p<.01), 0$ and $+10 \mathrm{~dB}(p<.01)$, and +5 and $+10 \mathrm{~dB}(p<.01)$.

To confirm that the six HP sentence lists did not differ statistically on their intelligibility values, a one-way ANOVA was conducted with correct scores (expressed in percentages) as a dependent variable and list the sentences belonged to (list) as an independent variable with six levels. The results showed no significant effects of list, $F(5)=2.14, p>.05, \eta^{2}=.069$. Thus, the six HP sentences lists did not differ on their percent correct scores.

The same analysis was carried out for the LP sentences. Responses on the intelligibility test (expressed in percen-

Table 1 Percentiles corresponding to the percent correct scores obtained by the listeners in the three signal-to-noise (SNR) conditions for high-predictability (HP) and low-predictability (LP) sentences

\begin{tabular}{lllllllll}
\hline & & P5 & P10 & P25 & P50 & P75 & P90 & P95 \\
\hline 0-dB SNR & HP & 17 & 26 & 34 & 45 & 58 & 67 & 72 \\
& LP & 3 & 4 & 8 & 14 & 23 & 30 & 34 \\
5-dB SNR & HP & 66 & 72 & 77 & 84 & 86 & 93 & 93 \\
& LP & 22 & 27 & 36 & 42 & 48 & 55 & 55 \\
10-dB SNR & HP & 80 & 84 & 91 & 95 & 97 & 97 & 100 \\
& LP & 51 & 53 & 63 & 70 & 75 & 80 & 81 \\
\hline
\end{tabular}

tages of correct scores) were used as a dependent measure. A one-way ANOVA was performed with list the sentences belonged to (list), with six levels, as a factor. We found no significant effects of list, $F(5)=1.48, p>.05, \eta^{2}=.04$. Thus, the six lists of LP sentences did not differ with regard to their percent correct scores.

\section{Creation of final forms}

The second step was to create final forms that would contain both HP and LP sentences. These forms were the result of combining one of the HP sentences lists with one LP sentence list in the following manner: list 1 (HP) with list 2 (LP), called form 1; list 2 (HP) with list 3 (LP), called form 2; list 3 (HP) with list 4 (LP), called form 3; list 4 (HP) with list 5 (LP), called form 4; list 5 (HP) with list 6 (LP), called form 5; and list 6 (HP) with list 1 (LP), called form 6 . Thus, the final test instrument contains six forms of 50 sentences each. Within each form, the order of presentation of the HP and LP sentences was randomized. This manner of presentation is the same as that used in the SPIN sentences by Kalikow et al. (1977).

Previously, we confirmed that the HP lists were equivalent in their percent correct scores, as were the LP lists. The next question was to find out whether the final six forms (resulting from the combination of one HP sentence list and one LP sentence list) continued to be equivalent in percent correct scores and phonetic content (the predictability of the final forms did not have to be measured, because this characteristic concerns only the HP sentences and it was tested in the previous study by Cervera \& Gonzalez-Alvarez, 2010).

Percent correct scores of the final forms of the test The means and standard deviations of the percent correct scores obtained in the present experiment, for each of the six final forms of sentences across the three SNR conditions, were calculated (see Table 2). In order to have forms that were equivalent in their percent correct scores, a one-way ANOVA was conducted with values of intelligibility (expressed as percentages of correct scores) as a dependent

Table 2 Means and standard deviations for the percent correct scores averaged for the three signal-to-noise ratios in the six forms (combination of highpredictability and lowpredictability sentences)

\begin{tabular}{lll}
\hline & \multicolumn{2}{l}{ Intelligibility } \\
\cline { 2 - 3 } & $M$ & $S D$ \\
\hline Form 1 & 40 & 23 \\
Form 2 & 39 & 24 \\
Form 3 & 38 & 26 \\
Form 4 & 36 & 23 \\
Form 5 & 38 & 22 \\
Form 6 & 40 & 28 \\
\hline
\end{tabular}


variable and form the sentences belonged to as an independent variable with six levels. The results showed no significant effects of the form to which the sentences belonged, $F(5)=1.49, p>.05, \eta^{2}=.25$. Thus, it can be concluded that the six final forms of sentences (containing $25 \mathrm{HP}$ and $25 \mathrm{LP}$ sentences) did not differ in their percent correct scores.

Phonetic content of the final forms of the test Another aim of the present study was for the final forms of 50 sentences to have similar equivalent phonetic content. The phonetic counts in each phonetic category were performed separately for the last word of the sentences and for the whole sentence (the preceding context plus the last word). In these counts, only content words (verbs, nouns, and adjectives) were taken into account, while articles, prepositions, and adverbs were not considered. The phonetic counts were calculated by counting the number of occurrences of segments in each phoneme class (occlusives, fricatives, nasals, liquids, and vowels). Phonetic counts were performed by the authors, who had training in this task.

A distribution of frequencies for each phoneme class was obtained for each of the 300 sentences (150 HP sentences and $150 \mathrm{LP}$ sentences), for the whole sentence and for the final word in the sentences alone. Table 3 shows the number of occurrences of each phoneme class for each of the six final forms.

In order to test whether all the forms had equivalent phonetic contents, a chi-square analysis was performed. Two separate tests were performed, for the final words or key words alone and for the whole sentences. Phoneme class (occlusives, fricatives, nasals, liquids, and vowels) and form (six levels) were included as factors in both cases. The chi-square value was not significant for the whole sentences, $\chi^{2}(20)=8.13, p>.05$, or for the final words of the sentence, $\chi^{2}(20)=9.66, p>.05$. Thus, the six final forms were equivalent in their phonetic content, whether the whole sentence was considered or only the final words. Finally, the definitive forms containing both HP and LP sentences are presented in the Appendix.

\section{Discussion}

Our objective was to generate forms of HP and LP Spanish sentences equivalent in intelligibility (measured as percent correct scores obtained in the perceptual task). These types of sentences have many applications, especially in psycholinguistics and audiology. In psycholinguistics, they could be especially useful in those circumstances in which it would be interesting to assess the sensory or bottom-up processing and the cognitive (effective use of context) or top-down processing capabilities of listeners during language processing. Some examples would be elderly listeners with age-related hearing loss but with intact topdown processing skills, children learning a second language who are not yet completely able to use context to accomplish speech perception, or individuals learning a second language with different levels of language proficiency. In audiology, these sentences can be useful for evaluating hearing aids in different SNR conditions simulating a variety of everyday communicative situations.

As in the case of the SPIN sentences (Kalikow et al., 1977) for the English language, the sentences developed in the present study for the Spanish language are easy to administer. The duration is short (about $10 \mathrm{~min}$ per form). The response required by the listeners is simple, because he or she has to respond only with the final word of the sentence. Besides intelligibility (percent correct scores),
Table 3 Number of occurrences in each phoneme class for the last word and the whole sentence for each form (combination of high-predictability [HP] and low-predictability sentences)

\begin{tabular}{lllllll}
\hline \multicolumn{5}{c}{ Phoneme class } & & \\
\cline { 3 - 6 } & & Occlusives & Fricatives & Nasals & Liquids & Vowels \\
\hline Form 1 & Last word & 45 & 24 & 10 & 30 & 96 \\
& Whole sentence & 170 & 83 & 66 & 111 & 381 \\
Form 2 & Last word & 39 & 26 & 18 & 26 & 98 \\
& Whole sentence & 162 & 87 & 88 & 92 & 386 \\
Form 3 & Last word & 45 & 35 & 18 & 24 & 106 \\
& Whole sentence & 176 & 91 & 82 & 101 & 398 \\
Form 4 & Last word & 50 & 34 & 17 & 27 & 111 \\
& Whole sentence & 164 & 99 & 71 & 106 & 404 \\
Form 5 & Last word & 50 & 30 & 20 & 29 & 105 \\
& Whole sentence & 164 & 76 & 72 & 98 & 351 \\
Form 6 & Last word & 50 & 29 & 13 & 30 & 98 \\
& HP whole sentence & 176 & 88 & 76 & 111 & 385 \\
\hline
\end{tabular}


other characteristics are also controlled, such as phonetic content, sentence length, final word stress, and final word frequency, all of which are quite relevant in audiological evaluation. The utility of the SPIN sentences (Kalikow et al., 1977) has been demonstrated by their utility in audiology and psycholinguistics. For the audiological evaluation of Spanish-speaking listeners or research conducted with Spanish-speaking listeners, it is necessary to have similar speech materials for the Spanish language.

Acknowledgments This research was supported in part by Research Grant PSI 2009-10067 (Ministry of Science and Technology of Spain).

\section{Appendix}

Table 4 Sentence forms. (H) and (L) indicate high and low predictability, respectively

Form 1

(H) 1. En el castillo se alza la torre

(H) 2. La explosión causó un caos

(L) 3. Ha estado pronunciando cera

(H) 4. Iba vestida con falda y blusa

(L) 5. Ellos escribieron cima

(L) 6. Pronuncia la palabra burro

(H) 7. Ata el regalo con una cinta

(L) 8. Ahora voy a decir cita

(H) 9. Guardó el dinero en el bolso

(L) 10. Ella dijo la palabra clima

(L) 11. Y a continuación dijo danza

(L) 12. No temas hablar del metro

(H) 13. Me tocó el primer premio

(H) 14. Es un gran salón de baile

(L) 15. No discutieron sobre una mueca

(H) 16. Hay que limpiar, hay mucho polvo

(H) 17. El río sigue por su cauce

(H) 18. El ladrón pertenece a la banda

(L) 19. Tu oíste que decía sopa

(L) 20. Está interesado en decir guía

\section{Form 2}

(L) 1. Ha estado pronunciando pase

(H) 2. Voy al museo de cera

(L) 3. Ellos escribieron lujo

(H) 4. Pronto alcanzarán la cima

(L) 5. Pronuncia la palabra mapa

(L) 6. Ahora voy a decir gallo

(L) 7. Ella dijo la palabra pata

(H) 8. Iba cargado como un burro

(H) 9. Llegó una hora tarde a su cita

(L) 10. Y a continuación dijo noble

(L) 11. No temas hablar del trozo

(H) 12. Dicen que habrá un cambio de clima

(L) 13. No discutieron sobre el gozo

(L) 14. Tu oíste que decía uñas

(H) 15. Yo estudio música y danza

(H) 16. Voy al trabajo en metro

(L) 17. Ha estado pronunciando beso

(H) 18. Torció la boca en una mueca

(L) 19. Juan no discute de la norma

(L) 20. Espero que hables de una ducha
Table 4 (continued)

(H) 21. Amontónalo en una pila

(H) 21. Tómate caliente la sopa

(L) 22. Juan no discute del lago

(H) 22. Todos seguíamos al guía (H) 23. Disparó con las flechas el
arco

(H) 23. Tiene una casa junto a un lago

(H) 24. Cruzó el charco de un

(L) 24. La niña sabía decir seda salto

(L) 25. Espero que hables de una (L) 25. Laura no pudo hablar del rama taxi

(L) 26. La niña sabía decir raya

(H) 26. Tengo que podar esa rama

(H) 27. Le gusta escurrir el bulto

(L) 27. Les oí que hablaban de la selva

(L) 28. Laura no pudo hablar del (H) 28. Te has pasado de la raya hielo

(H) 29. Lleva la compra en la bolsa

(L) 29. Carlos habló sobre la misa

(H) 30. Me convenció con malas artes

(L) 31. Les oí que hablaban del banco

(L) 32. Carlos habló sobre la gala

(L) 32. Estábamos pensando en unas rosas

(L) 33. Deberías poder decir alba

(L) 33. Ayer Luis soñó con unos toros

(H) 34. Bebe la leche de la taza

(H) 34. Tengo el dinero en el banco

(L) 35. Estábamos pensando en $(\mathrm{H})$ 35. Se requiere vestido de un plato gala

(H) 36. No suelen comer carne de cerdo

(L) 36. Ellos no consideraron el palo

(L) 37. Ayer Luis soñó con un trago (H) 38. Nos recibió en pijama y

(L) 37. Ahora voy a decir curas

(H) 39. De la cloaca salió una rata

(H) 38. Dormimos hasta el alba

(L) 40. Ellos no consideraron la firma

(L) 39. Es probable que hablen de unas venas

(L) 41. Laura estaba pronunciando polo

(L) 40. No creas que voy a decir tinta

(H) 41. Se dejó la comida en el plato

(H) 42. Se revolcó en el sucio barro

(H) 42. Se bebió el vino de un trago

(H) 43. En el cielo hay bandadas de aves

(H) 44. Son auténticos perros de caza

(H) 43. La carta lleva su firma

(L) 45. Es probable que hablen de unos gases

(L) 44. Lo que esta describiendo es la tela

(H) 45. Refresca mucho chupar un polo

(L) 46. No creas que voy a decir (H) 46. Reduce la emisión de muro gases

(H) 47. Soplaba una suave brisa

(H) 47. Por fin han derribado el muro

(L) 48. Lo que esta describiendo (L) 48. Adivina lo qué es un es la pausa chino

(H) 49. Todo se repite en un ciclo

(H) 49. Paramos para hacer una pausa

(L) 50. Adivina lo qué son unas (H) 50. Para leer necesita gafas gafas

Form 3

Form 4

(H) 1. Para entrar necesitas un pase
(H) 1. La escayola inmoviliza el hueso 
Table 4 (continued)

(L) 2. La lengua mas hablada es (L) 2. Ha estado pronunciando
el chino

(H) 3. Colecciona objetos de (L) 3. Ellos escribieron pasta lujo

(H) 4. Nos guiamos siguiendo el (H) 4. La actriz no soportó la mapa fama

(L) 5. Ha estado pronunciando (L) 5. Pronuncia la palabra olas hueso

(H) 6. Nos despertó el canto del (H) 6. Juega al ajedrez y las gallo

(L) 7. Ellos escribieron fama

(H) 8. No quiero meter la pata

(H) 9. Sirve a una causa muy noble

(L) 10. Pronuncia la palabra damas

(H) 11. No lo acabes, guárdame un trozo

(L) 12. Laura estaba pronunciando mozo

(H) 13. No cabía en sí de gozo

(L) 14. Ella dijo la palabra pico

(H) 15. No arañes con esas uñas

(H) 16. Se despidió con un beso

(H) 17. Me obligan a seguir esa norma

(L) 18. Y a continuación dijo dudas

(L) 19. No temas hablar de unas joyas

(H) 20. Me gusta cantar en la ducha

(H) 21. Llevaba un pañuelo de seda

(L) 22. No discutieron sobre unas nubes

(L) 23. Tu oíste que decía letra

(H) 24. Llego tarde, cogeré un taxi

(L) 25. Está interesado en decir venta

(H) 26. Los leones viven en la selva

(H) 27. Los católicos van a misa

(L) 28. Juan no discute de un disco

(L) 29. Espero que hables de una jaula

(H) 30. Lo mediré con una regla

(L) 31. La niña sabía decir culto

(L) 32. Laura no pudo hablar de la droga

L) 13. No temas hablar del cero

(H) 14. Guarda bien el dinero y las joyas

(L) 15. No discutieron sobre la rueda

(H) 16. En el cielo no se ven nubes

(L) 17. Tu oíste que decía falda

(L) 18. Está interesado en decir susto

(L) 19. Juan no discute de las vías

(H) 20. Fue escrito con su propia letra

(L) 21. Espero que hables de un duelo

(H) 22. Este piso no está en venta

(L) 24. Laura no pudo hablar de la culpa

(H) 25. Estás rayado como un disco

(H) 26. Estaba encerrado en la jaula

(H) 27. Es un sagrado lugar de culto

(L) 28. Les oí que hablaban de un trono

(H) 29. Es un consumidor de droga
Table 4 (continued)

$\begin{array}{lll}\text { (L) 33. Les oí que hablaban del } & \text { (L) 33. Deberías poder decir }\end{array}$ cuero

duque

(H) 34. Le regaló un ramo de rosas

(L) 35. Carlos habló sobre la dosis

(H) 34. Es el primero de la fila

(H) 36. Le gusta el fútbol y los toros

(H) 35. Es el militar de más rango

(L) 37. Deberías poder decir fila

(L) 36. Estábamos pensando en una pista

(L) 37. Ayer Luis soñó con unas rocas

(L) 38. Estábamos pensando en el (H) 38. Es el colmo de todos los rango males

(L) 39. Ayer Luis soñó con los males

(H) 39. Firmó un cheque con muchas cifras

(H) 40. Le golpeó con un palo

(L) 40. Ellos no consideraron al novio

(L) 41. Ellos no consideraron las cifras

(L) 41. Laura estaba pronunciando nieto

(L) 42. Laura estaba pronunciando lobo

(H) 42. Era tan fiero como un lobo

(L) 43. Es probable que hablen de una vela

(H) 43. Enciende la mecha de esa vela

(H) 44. Juan fue a un colegio de curas

(L) 44. Es probable que hablen de un verso

(H) 45. La sangre corre por sus venas

(H) 45. En matemáticas es un genio

(L) 46. No creas que voy a decir genio

(L) 46. No creas que voy a decir plumas

(L) 47. Lo que esta describiendo es el voto

(L) 47. Lo que esta describiendo es la dueña

(H) 48. La pluma mancha de tinta $(\mathrm{H})$ 48. En la urna deposito el voto

(L) 49. Adivina lo qué es un rayo (H) 49. En la tormenta cayó un rayo

(H) 50. La modista compra una tela

(L) 50. Adivina lo qué es un metal

\section{Form 5}

Form 6

(L) 23. La niña sabía decir daños

(L) 1. Está interesado en decir funda

(L) 1. Ha estado pronunciando torre

(L) 2. Ellos escribieron canto

(H) 2. Mete la guitarra en su funda

(H) 3. En la cola espero mi turno (L) 3. Ellos escribieron caos

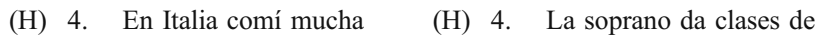
pasta canto

(L) 5. Pronuncia la palabra hoja (H) 5. Corta el tallo y las hojas

(L) 6. Ahora voy a decir llave $\quad$ (H) 6. Para abrir la puerta tengo llave

$\begin{array}{lll}\text { (H) 7. En el mar hay grandes } & \text { (L) 7. Pronuncia la palabra blusa }\end{array}$ olas

(L) 8. Ella dijo la palabra presa (L) 8. Ahora voy a decir cinta

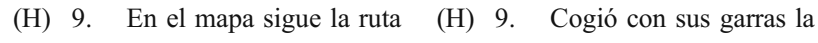
presa

(L) 10. Y a continuación dijo (L) 10. Ella dijo la palabra bolso túnel

(H) 11. En el informe nos falta un (L) 11. Y a continuación dijo dato premio

(L) 12. No temas hablar del coro (H) 12. El tren entró en el oscuro túnel 
Table 4 (continued)

(L) 13. No discutieron sobre el carro

(H) 14. Fue herido con una lanza

(H) 15. La nota mínima es un cero

(L) 16. Tu oíste que decía ríos

(H) 17. En el camino pinché una rueda

(L) 18. Está interesado en decir pulso

(L) 19. Juan no discute de la nuca

H) 20. El viento levantó su falda

(H) 21. Casi me muero del susto

(L) 22. Espero que hables de unas moscas

(L) 23. La niña sabía decir cuna

(L) 24. Laura no pudo hablar de la copa

(H) 25. El tren circula por las vías

(H) 26. El silencio fue en señal de duelo

(L) 27. Les oí que hablaban de unas bromas

(H) 28. El seguro cubrirá los daños

(H) 29. Ella cargó con toda la culpa

(L) 30. Carlos habló sobre la trama

(L) 31. Deberías poder decir cola

(H) 32. El rey se sienta en su trono

(L) 33. Estábamos pensando en una fila

(H) 34. El pescador recoge las redes

(L) 35. Ayer Luis soñó con la trampa

(H) 36. El palacio pertenece al duque

(L) 37. Ellos no consideraron la tienda

(H) 38. El detective sigue la pista

(L) 39. Laura estaba pronunciando dardo

(L) 40. Es probable que hablen de la luna

(H) 41. El barco encalló en las rocas

(L) 42. No creas que voy a decir trozos

(H) 43. El anillo se lo puso el novio

(H) 44. El abuelo cuida de su nieto
(L) 13. No temas hablar del baile

(L) 14. No discutieron sobre el polvo

(H) 15. Canta de tenor en un coro

(L) 16. Tu oíste que decía cauce

(H) 17. El caballo tira del carro

(H) 18. Al mar van a desembocar los ríos

(L) 19. Está interesado en decir banda

(L) 20. Juan no discute de la pila

(H) 21. Al correr se me acelera el pulso

(H) 22. Al caer se dio en la nuca

(L) 23. Espero que hables de un arco

(L) 24. La niña sabía decir salto

(H) 25. A la miel acuden las moscas

(L) 26. Laura no pudo hablar del bulto

(H) 27. Deja el niño en la cuna

(L) 28. Les oí que hablaban de una bolsa

(H) 29. Brindamos alzando la copa

(L) 30. Carlos habló sobre las artes

(L) 31. Deberías poder decir taza

(H) 32. El siempre gasta pesadas bromas

(H) 33. La historia tiene una buena trama

(L) 34. Estábamos pensando en un cerdo

(L) 35. Ayer Luis soñó con una bata

(H) 36. Espere su turno en la cola

(H) 37. Tengo asiento en primera fila

(H) 38. El ratón cayo en la trampa

(L) 39. Ellos no consideraron la rata

(H) 40. Acampamos con nuestras tiendas

(H) 41. El sabe como lanzar un dardo

(L) 42. Laura estaba pronunciando barro

(L) 43. Es probable que hablen de unas aves

(H) 44. De noche hay luz de luna
Table 4 (continued)

(L) 45. Lo que esta describiendo (H) 45. Corta la carne en es el choque

pequeños trozos

(H) 46. El poeta le escribió un verso

(L) 46. No creas que voy a decir caza

(H) 47. Duermo con un cojín de plumas

(L) 47. Lo que esta describiendo es la brisa

(L) 48. Adivina lo qué es un pito (H) 48. No hubo heridos en el choque

(H) 49. Devuelve lo robado a su dueña

(H) 49. El árbitro hizo sonar el pito

(H) 50. Es austero como un

(L) 50. Adivina lo qué es un ciclo monje

Note. The audio files corresponding to the sentences are available at $\mathrm{http} / / / \mathrm{www} . u v . e s / \sim$ cervera, or they can be obtained in electronic form from the authors.

\section{References}

Bilger, R. C., Nueltzel, J. M., Rabinowitz, W. M., \& Rzeczkowsky, C. (1984). Standardization of a test of speech perception in noise. Journal of Speech and Hearing Research, 27, 32-48.

Cervera, T., \& Gonzalez-Alvarez, J. (2010). Lists of Spanish sentences with equivalent predictability, phonetic content, length and frequency of the last word. Perceptual and Motor Skills, 111(2), 517-529. doi:10.2466/28.PMS.111.5.517.529

Del Dot, J., Hickson, L. M., \& O'Connell, B. (1992). Speech perception in noise with BICROS hearing aids. Scandinavian Audiology, 21, 261-264.

Dubno, J. R., Ahlstrom, J. B., \& Horwitz, A. R. (2000). Use of context by young and aged adults with normal hearing. The Journal of the Acoustical Society of America, 107, 538-546.

Elliot, L. L. (1979). Performance of children aged 9 to 17 years on a test of speech intelligibility in noise using sentence material with controlled word predictability. The Journal of the Acoustical Society of America, 66, 651-653.

Gordon-Salant, S., \& Fitzgibbons, P. J. (1997). Selected cognitive factors and speech recognition performance among young and elderly listeners. Journal of Speech and Hearing Research, 40, 423-431.

Gordon-Salant, S., \& Fitzgibbons, P. J. (1999). Profile of auditory temporal processing in older adults. Journal of Speech, Language, and Hearing Research, 42, 300-311.

Gordon-Salant, S., \& Fitzgibbons, P. J. (2001). Sources of age-related recognition difficulty for time-compressed speech. Journal of Speech, Language, and Hearing Research, 44, 709-719. doi:10.1044/1092-4388(2001/056)

Gordon-Salant, S., \& Fitzgibbons, P. J. (2004). Effects of stimulus and noise rate variability on speech perception by younger and older adults. The Journal of the Acoustical Society of America, 115, $1808-1817$.

Gordon-Salant, S., Fitzgibbons, P. J., \& Friedman, S. A. (2007). Recognition of time-compressed and natural speech with selective temporal enhancements by young and elderly listeners. Journal of Speech and Hearing Research, 50, 1181-1193. doi:10.1044/1092-4388(2007/082) 
Goy, H., Pichora-Fuller, M. K., van Lieshout, P., Singh, P., \& Schneider, B. A. (2007). Effect of within- and between-talker variability on word identification in noise by younger and older adults. Canadian Acoustics, 35, 108-109.

Humes, L. E., Burk, M. H., Coughlin, M. P., Busey, T. A., \& Strauser, L. E. (2007). Auditory speech recognition and visual text recognition in younger and older adults: Similarities and differences between modalities and the effects of presentation rate. Journal of Speech, Language, and Hearing Research, 50, 283303. doi:10.1044/1092-4388(2007/021)

Hutcherson, R. V., Dirks, D. D., \& Morgan, D. E. (1979). Evaluation of the speech perception in noise (SPIN) test. Otolaryngology Head and Neck Surgery, 87, 239-245.

Kalikow, D. N., Stevens, K. N., \& Elliot, L. L. (1977). Development of a test of speech intelligibility in noise using sentence materials with controlled word predictability. The Journal of the Acoustical Society of America, 5, 1337-1360.

Mayo, L. H., Florentine, M., \& Buus, S. (1997). Age of secondlanguage acquisition and perception of speech in noise. Journal of Speech, Language, and Hearing Research, 40, 686-693.

Perry, A. R., \& Wingfield, A. (1994). Contextual encoding by young and elderly adults as revealed by cued and free recall. Aging and Cognition, 1, 120-139.
Pichora-Fuller, M. K. (2008). Use of supportive context by young and older adult listeners: Balancing bottom-up and top-down information processing. International Journal of Audiology, 47(Suppl. 2), S72-S82. doi:10.1080/14992020802307404

Pichora-Fuller, M. K., Schneider, B. A., \& Daneman, M. (1995). How young and old adults listen and remember speech in noise. The Journal of the Acoustical Society of America, 97, 593-608.

Pichora-Fuller, M. K., Schneider, B. A., MacDonald, E., Pass, H. E., \& Brown, S. (2007). Temporal jitter disrupts speech intelligibility. Hearing Research, 223, 114-121. doi:10.1016/j. heares.2006.10.009

Sheldom, S., Pichora-Fuller, M. K., \& Schneider, B. A. (2008). Effects of age, presentation method, and learning on identification of noise vocoded words. The Journal of the Acoustical Society of America, 123, 476-488.

Sommers, M. S., \& Danielson, S. M. (1999). Inhibitory processes and spoken word recognition in young and old adults: The interaction of lexical competition and semantic context. Psychology and Aging, 14, 458-472. doi:1037/0882-7974.14.3.458

Wingfield, A., Tun, P. A., \& McCoy, S. L. (2005). Hearing loss in older adulthood: What it is and how it interacts with cognitive performance. Current Directions in Psychological Sciences, 14, 144-148. 